\title{
Mapping of Processed Food Product Innovation on Small and Medium Enterprises in Banten
}

\author{
Fauji Sanusi \\ Faculty of Economics and Business \\ Universitas Sultan Ageng Tirtayasa \\ Banten Province, Indonesia \\ fauji.sanusi@untirta.ac.id
}

\author{
Gerry Ganika Koswara \\ Laboratory of Business Management \\ Universitas Sultan Ageng Tirtayasa \\ Banten Province, Indonesia \\ gega@untirta.ac.id
}

\begin{abstract}
The purpose of this study is to create a mapping of small and medium enterprises (SMEs) based on their internal innovation and external conditions. The model used for mapping is Quantified-SWOT analysis by adopting the concept of Multiple-Attribute Decision Making (MADM) to simplify complex problems so analysis can be carried out on several companies simultaneously. This model was tested using case study on 60 SMEs of processed food products in Lebak and Serang District, Banten. Results show that product innovation internal factors (IFE) at the observed SMEs has a value of 2.67 (on 5 scales), and external factors (EFE) that support their development are 2.51 (on 5 scales), which are both values in a weak category. However, the overall position of SMEs in the SWOT matrix coordinate is $[0.122 ;-\mathbf{0 . 2 8 8}]$ which located in quadrant III. It can be interpreted that SMEs are still in a weak condition and require diversification strategies. This study also provides several recommendations to improve innovation capabilities both internally and externally. Based on Weighted Value Analysis, the priority recommendations are in improving on internal side of SMEs, which are production process innovation and increasing access to the internet, while from the external side (for the government) priority recommendations are developing a market information system for SMEs, and lowering loan interest rate policy to be more pro-SMEs-oriented.
\end{abstract}

Keywords: SME's Mapping, Quantified-SWOT Analysis, Multiple-Attribute Decision Making, SWOT Matrix, Internal Factor Evaluation, External Factor Evaluation

\section{INTRODUCTION}

Innovations have been widely discussed in various scientific and technical literature, including in the social and economic sciences. (Godin, 2008) concludes that the history of genealogy is innovation through three developmental concepts namely imitation $\rightarrow$ invention $\rightarrow$ innovation. So, in this considerate, innovation is seen as the last series of processes of forming, discovering and developing values into modern scientific practices. Innovation in management science described as a managerial process, in accordance with the definition of innovation from (Baregheh, Sambrook, \& Rowley, 2009) which states that "Innovation is the multi-stage process in which organizations are transformed into new products, services or processes in order to advance, compete and differentiate them as successfully in their marketplace." Similarly, (Varis \& Littunen, 2010) divides innovation into two parts, first, innovation refers to the object of change, namely: product innovation, process innovation, market innovation, and organizational innovation. Second, innovation is based on the level of change, namely complete (radical) novelty and or significant improvement.

Ul Hassan, Shaukat, Nawaz, and Naz (2013) emphasized the importance of product innovation as one of the key factors of organizational success and an important strategy for increasing market share and business performance. Product innovation is an effort carried out by the organization in developing a completely new infrastructure or in the form of significant improvements from existing products. This can be related to changes in the functional characteristics of the product, technical specifications, components, friendliness in use or other functional characteristics (OECD, 2005).

Product innovation is determined by two main factors, namely internal factors, and external factors. Internal factors can be in the form of competency-derived capabilities of the company, firm's technological competences, in-house R \& D (Vega-Jurado, Gutiérrez-Gracia, Fernández-de-Lucio, \& Manjarrés-Henríquez, 2008), learning by doing, and experimentation on purpose. On the other hand, product innovation can also be determined by external factors such as suppliers, buyers, and government policies (Geenhuizen \& Indarti, 2005). A strong combination of these two factors has been proven to improve and accelerate the process of innovation in the company (Katz, du Preez, \& Louw, 2016; Ozkaya, 2011; Vega-Jurado et al., 2008).

Product innovation carried out by a company must be based on market developments, including for SMEs. Many studies have proven that SMEs are more capable and easier to innovate radically than larger companies (Geenhuizen \& Indarti, 2005; Kanter, 1985; Myers, Oke, \& Burke, 2007; Nassimbeni, 2001; Soto-Acosta, Popa, \& Palacios-Marqués, 2016) so that SMEs are considered to be more preferable in facing market dynamics. 
In Indonesia, SMEs are one of the most important pillars in the national economy, SMEs in number is more than 26 million or $90 \%$ of the total business units (BPS, 2016) ${ }^{1}$. If regard in numbers, the growth in the SMEs sector in Indonesia is expected to accelerate macroeconomic growth. Especially in Banten Province, there were more than 477 thousand small and medium-sized business units, and hiring 887 thousand workers, so, that SMEs expect could become the driving force economic growth in Banten Province.

Given the important role of SMEs in economic and community development, systematic efforts are needed to strengthen and develop SMEs. Therefore, it is hoped that this research can be a reference in determining policies aimed at developing SMEs, especially in Banten province.

Development policies of SMEs in Indonesia, regulated on State Law (undang-undang) number 20 of 2008 about Micro, Small-scale Enterprises and Medium-sized Enterprises (MSMEs), states that MSMEs must be organized and supported in a comprehensive, optimal, and sustainable manner through the development of a conducive climate, provision of business opportunities, protection and business development to widest possible extent. So its clear, position of SMEs in Indonesia has a strategic position in realizing economic growth, equity and increasing people's income, job creation, and poverty alleviation. In addition, the Indonesian government has constituted regulation number 17 of 2013 about Micro, Small Business and Medium Enterprises (MSMEs) as a cornerstone in realizing and optimizing the role of MSMEs in building the national economy.

Scrutinize of SMEs role in the economy and community development, it is needed systematic efforts to strengthen and develop SMEs, therefore, this research expected to be a reference in determining policies intended to developing SMEs, especially in Banten province.

\section{LITERATURE REVIEW}

\section{Resource-based Theory}

Barney (1991) defines resources as all assets, organizational capabilities or processes, company attributes, information, knowledge, and others, which can be controlled by the company and can be used to achieve its strategic objectives effectively and efficiently. The Resource-based theory states that resources will be very heterogeneous between companies and not easy to be transferred to other (resource immobility), heterogeneity and immobility of these assets that are able to create competitive advantages for companies in the industry. This explains why the resources that have been owned and developed will be more dominant or advance than the types of resources that are obtained openly.

Internally, every company has unique competencies compared to other companies. The main factor determines a company's competitive position is a process of formulating

\footnotetext{
${ }^{1}$ http://se2016.bps.go.id/Lanjutan/index.php/site/tabel?tid=5\&wid=0\#, access $6 / 10 / 2018$
}

strategies based on company's internal capabilities (Lidija \& Robert, 2014). For SMEs, product innovations originating from their internal capabilities will be more effective and efficient.

\section{Innovation among SMEs}

Barnet (1953) simply defines innovation as the introduction of something new. Several years later, (Thompson, 1965) provided a broader definition of innovation that was interpreted as the renewal, acceptance, and implementation of new ideas, new processes, new goods and services. In the era of the 90's the definition of innovation was broadened, as stated by (Amabile, Contti, Coon, Lazenby, \& Herron, 1996) which defines innovation as the successful implementation of creative ideas in organizations. A more comprehensive definition is conveyed by (West \& Farr, 1990), which defines innovation as an attempt to convey something new in a planned manner, the application of new products, processes, procedures, or new ideas designed to provide benefits for individuals, groups, organizations or wider society.

In the management science literature, innovation interpreted as a multidimensional concept. If it is associated with the growth of the company, it will find various dimensions of innovation in the form of product innovation, process, service, market, logistics and organizational innovations (Geenhuizen \& Indarti, 2005; Soto-Acosta et al., 2016). Companies such as SMEs can not only implement one form of innovation but can implement several innovations at once. The success of SMEs in conducting innovation has been proven in several research (Anderson, Potočnik, \& Zhou, 2014; Ghazalian \& Fakih, 2017; Ozkaya, 2011; Soto-Acosta et al., 2016; Walker, 2014)

\section{Methodology}

The object of this research is SMEs of processed food products in Lebak and Serang District, Banten. Data collection was carried out in a survey with random sampling. The level of analysis is individual, this level of analysis should be taken within the present review (ter Haar, 2018). From 81 questionnaires was distributed, there were 21 questionnaires that were not included in analysis, this because the questionnaire was not returned and/or incomplete. Therefore, only 60 survey results were included in further analysis.

The model used for data analysis is Quantified-SWOT and Multi-Attribute Decision Making (MADM) to create measurement indicators hierarchically (Argawal, Grassl, \& Pahl, 2012; Chang \& Huang, 2006; GÜRel, 2017). Using MADM, 34 indicators were obtained from four main factors in SWOT analysis, each indicator is weighted based on the importance level, see table I \& II. To evaluate internal and external conditions, each indicator is given a scale of 5 and then we use a value 2.6 as a cut-off, it is to determine 
perceptual position of each indicator on SWOT category. Therefore, if perception value (mean of assessment score) is less than $(<) 2.6$ then the indicator is considered as weakness or threat. Conversely, if perception value is more than (>) 2.6 then the indicator is considered as strength or opportunity.

Quantified-SWOT Analysis chose as a model to map the condition of SMEs in Banten, mapping each SMEs position in the industry, identify potential SMEs, eliminate threats and concludes by delivering an internal strategy to compete and or suggest a government policy externally. The research flow is as follows:

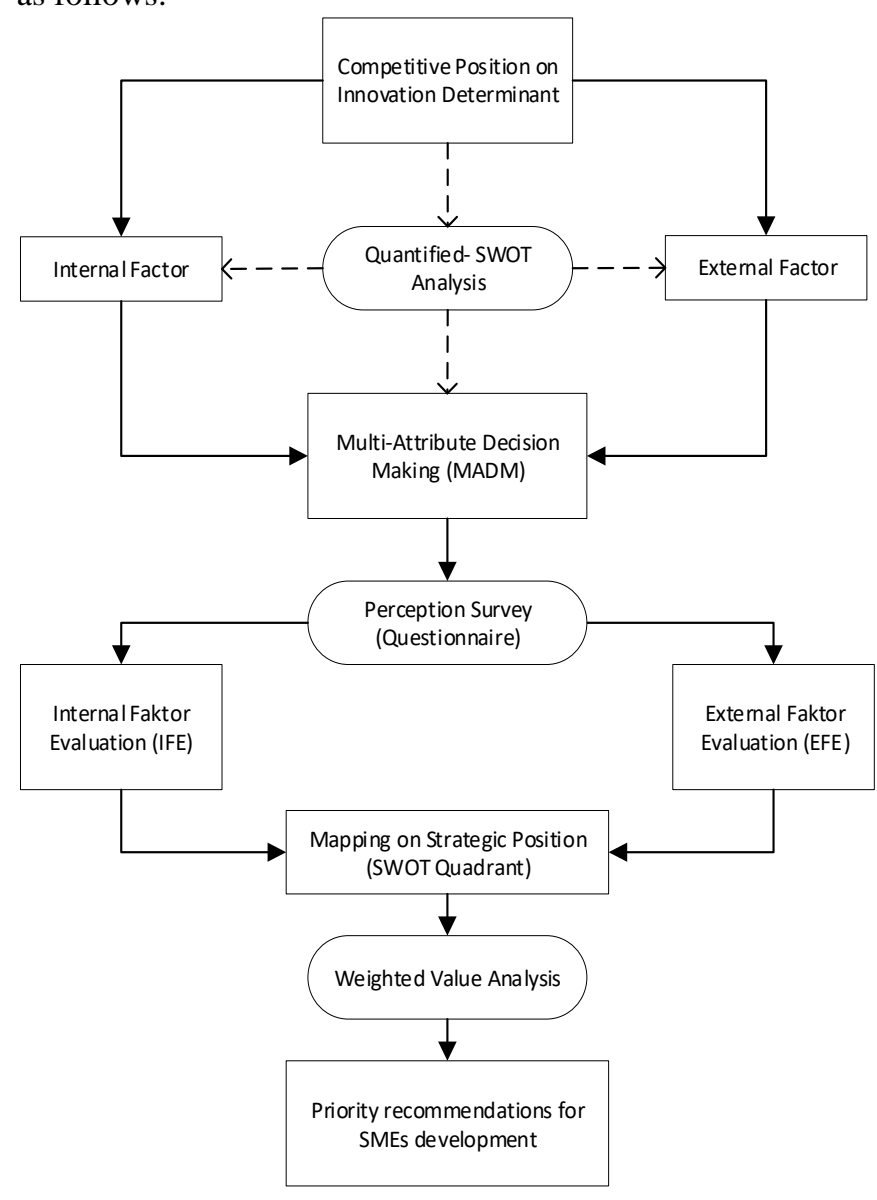

Fig. 1 Mapping Model of Processed Product Innovation SMEs in Banten Province.

\section{RESULT AND DISCUSSION}

Data analysis was performed on two main factors that construct the innovation, the internal factors, and external factors. Measurements were made using 16 internal indicators and 18 external indicators perceptually.

\section{A. Internal Factor Assessments Score}

Internal factor analysis was carried out using 16 indicators, from the results of the analysis found 9 indicators perceived as a source of strength for SMEs while 7 other indicators are still considered a source of weakness. The analysis results are presented in the following table I:

TABLE I

INTERNAL FACTOR ASSESSMENTS SCORE

\begin{tabular}{llccc}
\hline & Indicator & $\begin{array}{c}\text { Importance } \\
\text { Weight } \\
(W)\end{array}$ & $\begin{array}{c}\text { Assessment } \\
\text { s Score } \\
(a)\end{array}$ & $\begin{array}{c}\text { SWOT } \\
\text { Category } \\
\text { (cut off 2,6) }\end{array}$ \\
\hline D1 & $\begin{array}{l}\text { Row Material } \\
\text { diversifications }\end{array}$ & 0,055 & 1,62 & Weakness \\
\hline D2 & $\begin{array}{l}\text { Innovation on } \\
\text { Production Process }\end{array}$ & 0,095 & 2,03 & Weakness \\
\hline D3 & Product Development & 0,098 & 3,05 & Strength \\
\hline D4 & Packaging & 0,062 & 2,60 & Weakness \\
\hline D5 & $\begin{array}{l}\text { Innovation on } \\
\text { Marketing }\end{array}$ & 0,054 & 3,55 & Strength \\
\hline D6 & $\begin{array}{l}\text { End Product } \\
\text { Distribution }\end{array}$ & 0,045 & 2,58 & Weakness \\
\hline D7 & $\begin{array}{l}\text { Payment/sales } \\
\text { transaction } \\
\text { mechanism }\end{array}$ & 0,035 & 3,05 & Strength \\
\hline E1 & Ability to use Internet & 0,062 & 3,03 & Strength \\
\hline E2 & $\begin{array}{l}\text { Use of e-Commers } \\
\text { facilities }\end{array}$ & 0,045 & 2,45 & Weakness \\
\hline E3 & Access to the Internet & 0,075 & 2,47 & Weakness \\
\hline E4 & $\begin{array}{l}\text { Ability to use } \\
\text { Computer }\end{array}$ & 0,045 & 2,80 & Strength \\
\hline F1 & $\begin{array}{l}\text { Row material } \\
\text { procurement }\end{array}$ & 0,065 & 2,88 & Strength \\
\hline F2 & $\begin{array}{l}\text { Row Material } \\
\text { Availability }\end{array}$ & 0,075 & 2,63 & Strength \\
\hline F3 & Supply Shortage & 0,062 & 2,57 & Weakness \\
\hline F4 & Row Material channel & 0,062 & 3,07 & Strength \\
\hline F5 & $\begin{array}{l}\text { Stability of raw } \\
\text { material prices }\end{array}$ & 0,065 & 3,00 & Strength \\
\hline${ }^{*}$ Assessment Score (a) = mean each indicator \\
${ }^{* *}$ If (a) $>$ 2,6 = Strength; if $(a)<2,6=$ Weakness
\end{tabular}

Assessment results show that SMEs in Banten has several sources of strength to develop and innovate, for example by conducting marketing innovations (3.55), develop a raw material supply channel (3.07), product development (3.05), develop payment systems or banking-based transactions or other services $(3,05)$, has the ability to use the internet (3.03), stability in raw material prices (3.00), good raw material procurement (2.88), and managing the availability of raw materials $(2,63)$. While several other indicators are still in the weak category, particularly in diversifying raw materials (1.62), innovation in the production process (2.03), the use of e-commerce (2.45), access to the Internet (2.47), raw materials shortage (2.57), and packaging (2.60). 


\section{B. External Factor Assessments Score}

External factor analysis was carried out using 18 indicators, from that results of the analysis showed 5 indicators perceived as a source of opportunity for SMEs while 12 other indicators were still considered to be a source of weakness. Analysis results are presented in the following table II:

TABLE II

EXTERNAL FACTOR ASSESSMENTS SCORE

\begin{tabular}{|c|c|c|c|c|}
\hline & Indicator & $\begin{array}{l}\text { Importance } \\
\text { Weight } \\
(W)\end{array}$ & $\begin{array}{l}\text { Assessment } \\
\text { s Score }(a)\end{array}$ & $\begin{array}{c}\text { SWOT } \\
\text { Category } \\
\text { (cut off } 2,6 \text { ) }\end{array}$ \\
\hline A1 & $\begin{array}{l}\text { Infrastructure and } \\
\text { Transportation }\end{array}$ & 0,062 & 2,95 & Opportunity \\
\hline $\mathrm{A} 3$ & $\begin{array}{l}\text { Electricity and Clean } \\
\text { Water }\end{array}$ & 0,035 & 3,70 & Opportunity \\
\hline A5 & $\begin{array}{l}\text { Telecommunications } \\
\text { Network }\end{array}$ & 0,096 & 3,10 & Opportunity \\
\hline A6 & $\begin{array}{l}\text { Supporting } \\
\text { infrastructure for } \\
\text { business place }\end{array}$ & 0,015 & 2,27 & Threat \\
\hline B1 & $\begin{array}{l}\text { Assistance to capital } \\
\text { access }\end{array}$ & 0,062 & 1,62 & Threat \\
\hline B2 & $\begin{array}{l}\text { Integrated promotion } \\
\text { amenities from } \\
\text { government }\end{array}$ & 0,093 & 2,23 & Threat \\
\hline B3 & $\begin{array}{l}\text { Ease of business } \\
\text { administration }\end{array}$ & 0,042 & 3,33 & Opportunity \\
\hline B5 & $\begin{array}{l}\text { Interest Rate Policies } \\
\text { for Small Business }\end{array}$ & 0,085 & 2,52 & Threat \\
\hline B6 & $\begin{array}{l}\text { Other financial sector } \\
\text { policies }\end{array}$ & 0,035 & 1,60 & Threat \\
\hline B7 & $\begin{array}{l}\text { Market Information } \\
\text { System }\end{array}$ & 0,089 & 3,00 & Threat \\
\hline B8 & $\begin{array}{l}\text { Business licensing } \\
\text { mechanism }\end{array}$ & 0,032 & 3,72 & Opportunity \\
\hline $\begin{array}{c}\mathrm{B} 1 \\
0\end{array}$ & $\begin{array}{l}\text { Business development } \\
\text { assistance }\end{array}$ & 0,083 & 2,25 & Threat \\
\hline $\begin{array}{c}\text { B1 } \\
1\end{array}$ & IPR assistance & 0,035 & 2,12 & Threat \\
\hline $\begin{array}{l}\text { B1 } \\
2\end{array}$ & $\begin{array}{l}\text { raw material amenity } \\
\text { from the government }\end{array}$ & 0,025 & 2,27 & Threat \\
\hline $\mathrm{C} 1$ & Access to bank loan & 0,072 & 2,02 & Threat \\
\hline $\mathrm{C} 2$ & $\begin{array}{l}\text { Access to non- } \\
\text { banking loan }\end{array}$ & 0,035 & 2,50 & Threat \\
\hline $\mathrm{C} 4$ & $\begin{array}{l}\text { Loan term of } \\
\text { condition for small } \\
\text { business }\end{array}$ & 0,042 & 1,77 & Threat \\
\hline C5 & $\begin{array}{l}\text { Additional source of } \\
\text { working capital }\end{array}$ & 0,062 & 2,33 & Threat \\
\hline
\end{tabular}

Assessment results of external factors showed SMEs in Banten still need to develop, because there are still many indicators that are in the threat category, for example, government financial policies (1.62), assistance to increase capital access (1.62) and loan requirements for small businesses (1.77) is still considered burdensome to SMEs. In addition, there are several indicators of a good perceived, and categorized as opportunities for SME development, for example, business licensing (3.72) which is considered very easy, availability of electricity and water for production (3.70), availability of communication networks (3.10), and availability of infrastructure and transportation (2.95) which is good enough.

\section{Internal Factor Evaluation}

After an assessment of the various internal and external indicators, the next stage is an evaluation based on the weight of each indicator. Evaluation results of the internal condition of SMEs indicate IFE value of 2.695 of a scale of 5 (see Table III). If using a value of 2.6 as a cut-off, then the value of this IFE can be interpreted that in general SMEs processed food products have internal strength to innovate. Nevertheless, this internal strength still needs to be increased to above value 3.6 in order to SMEs of processed food products can compete in the global market

TABLE III

INTERNAL FACTOR ASSESSMENTS SCORE

\begin{tabular}{|c|c|c|}
\hline & Indicators & $\begin{array}{c}\text { Index } \\
\text { Value } \\
(a \times W)^{*}\end{array}$ \\
\hline D1 & Row Material diversifications & 0,089 \\
\hline D2 & Innovation on Production Process & 0,193 \\
\hline D3 & Product Development & 0,299 \\
\hline D4 & Packaging & 0,161 \\
\hline D5 & Innovation on Marketing & 0,191 \\
\hline D6 & End Product Distribution & 0,116 \\
\hline D7 & Payment/sales transaction mechanism & 0,107 \\
\hline E1 & Ability to use Internet & 0,189 \\
\hline E2 & Use of e-Commerce facilities & 0,110 \\
\hline E3 & Access to the Internet & 0,185 \\
\hline E4 & Ability to use Computer & 0,126 \\
\hline F1 & Row material procurement & 0,187 \\
\hline $\mathrm{F} 2$ & Row Material Availability & 0,197 \\
\hline F3 & Supply Shortage & 0,159 \\
\hline F4 & Row Material channel & 0,190 \\
\hline F5 & Stability of raw material prices & 0,195 \\
\hline
\end{tabular}

Index Value $=$ Assessment Score (a) $x$ Importance Weight $(W)$

"IFE Index $=\sum(a \times w)$; from 5 scale

\section{External Factor Evaluation Score}

Development of SMEs is not only determined by internal factors but also highly dependent on external conditions. Results of evaluation on external factors indicate an EFE value of 2.5268 (see table IV), this value can be interpreted that the external conditions of SMEs are imperfect to encourage product development and innovation for SMEs. The EFE value considered ideal for SME development is above 3.6. 
TABLE IV

EXTERNAL FACTOR ASSESSMENTS SCORE

\begin{tabular}{|c|c|c|}
\hline & Indicators & $\begin{array}{c}\text { Index } \\
\text { Value } \\
(a x w)\end{array}$ \\
\hline A1 & Infrastructure and Transportation & 0,183 \\
\hline A3 & Electricity and Clean Water & 0,129 \\
\hline A5 & Telecommunications Network & 0,298 \\
\hline A6 & Supporting infrastructure for business place & 0,034 \\
\hline B1 & Assistance to capital access & 0,100 \\
\hline $\mathrm{B} 2$ & Integrated promotion amenities from government & 0,208 \\
\hline B3 & Ease of business administration & 0,140 \\
\hline B5 & Interest Rate Policies for Small Business & 0,214 \\
\hline B6 & Other financial sector policies & 0,056 \\
\hline B7 & Market Information System & 0,267 \\
\hline B8 & Business licensing mechanism & 0,119 \\
\hline B10 & Business development assistance & 0,186 \\
\hline B11 & IPR assistance & 0,074 \\
\hline B12 & raw material amenity from the government & 0,057 \\
\hline $\mathrm{C} 1$ & Access to bank loan & 0,145 \\
\hline $\mathrm{C} 2$ & Access to non-banking loan & 0,087 \\
\hline $\mathrm{C} 4$ & Loan term of condition for small business & 0,074 \\
\hline \multirow[t]{2}{*}{$\mathrm{C} 5$} & Additional source of working capital & 0,145 \\
\hline & External Factor Evaluation (EFE) Index ${ }^{* * *}$ & 2,5168 \\
\hline
\end{tabular}

${ }^{*}$ Index Value $=$ Assessment Score (a) $x$ Importance Weight $(W)$

${ }^{* *} E F E$ Index $=\sum(a x w) ;$ from 5 scale

Referring to the index value of each indicator, the first order indicator is telecommunications network (0.298), and the next is market information system $(0.267)$, interest rate policy for small business (0.214), and integrated promotion amenities from the government (0.208). This can be interpreted that indicators above are the main determinant on improving SMEs innovation nowadays.

\section{E. Mapping on SWOT Diagram}

SME development process certainly cannot be sporadic but must do a structured and based on objective conditions in individual SMEs. Therefore, mapping needs to be done to facilitate the development process in accordance with the objective conditions of each SME.

Mapping results showed that more than $45 \%$ of SMEs that are observed have internal strength for innovation and business development. But overall the potential for SME development is still in quadrant III, which means that most SMEs have the power to innovate and develop but the majority still face constraints from the external side. Following are the results of mapping SMEs of processed food products in Banten province:

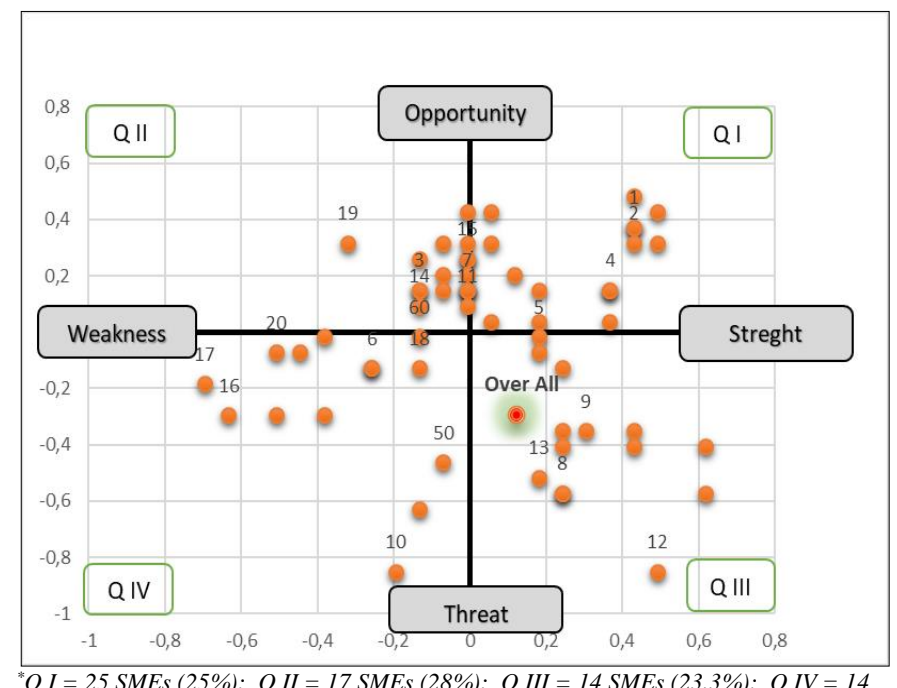

${ }^{*} Q I=25$ SMEs (25\%); $Q I I=17$ SMEs (28\%); $Q I I I=14$ SMEs $(23,3 \%) ; Q I V=14$ SMEs $(23,3 \%)$

Over All $=$ Q III

Note:

${ }^{*}$ Coordinate on $X$ axis (Internal factor $)=\sum$ (strength - weakness)

${ }^{* *}$ Coordinate on Y axis (External factor) $=\sum$ (Opportunity - Threat $)$

Fig. 2 Mapping Model of Processed Food Product Innovation SMEs in Banten Province.

Quadrant I - a condition was very potential to be developed. In this position, there are 15 or around $25 \%$ from SMEs were observed. SMEs in this position requires the development of an aggressive strategy or growth-oriented strategy. In general, SMEs in this position are SMEs that have strong bargaining power in the market so they are able to control market conditions, this is a determining factor of competitiveness.

Quadrant II - SMEs in this position has the advantage of external conditions or in other words have a big enough opportunity to continue to grow. However, from the internal side, it is still very weak so that the potential or opportunities that are likely to be wasted. Based on analysis, as many as 17 or $28 \%$ from SMEs was observed, were in this position. They require an internal partnership strategy or turnaround-style strategy that prioritizes internal development to capture more opportunities.

Quadrant III - SMEs in this position is the SMEs that have a good internal strength and has the potential to be developed, but they faced external threats were disrupt growth. As many as 14 or $23 \%$ from SMEs observed, was in this position. They require a diversification strategy, which uses internal strength to catch more opportunity thus can reduce the impact of existing threats. 
Quadrant IV - in this position, SMEs will face many obstacles in their development process. As many as 14 or $23 \%$ from SMEs observed, were in this position. They highly vulnerable to external threats. Their internal weakness makes they are not good enough to take advantage of existing opportunities, and many threats that cannot be eliminated that causes SMEs in this position have no bargaining power in the market.

\section{F. SMEs Priority Improvement Index}

To improve the condition and position of SMEs to be more innovative and competitive, a priority scale is needed by decision makers. This research uses Weighted Value Analysis to produces a priority index based on each factor importance level, thus this analysis obtains a sequence of indicators that can be implemented on SMEs development. Improvement priorities are presented in the following Table $\mathrm{V}$ :

TABLE V

Priority Improvement Index

\begin{tabular}{clc}
\multicolumn{2}{c}{ External Factor Priority Improvement } & \\
\hline \multicolumn{2}{c}{ Indicator } & $\begin{array}{c}\text { Priority Index } \\
\text { (P index) }\end{array}$ \\
\hline B7 & Market Information System & 0,0445 \\
B5 & Interest Rate Policies for Small Business & 0,0396 \\
\hdashline B2 & Integrated promotion amenities from government & 0,0391 \\
\hdashline B10 & Business development assistance & 0,0349 \\
\hline C5 & Additional source of working capital & 0,0285 \\
\hline C1 & Access to bank loan & 0,0281 \\
\hline C2 & Access to non-banking loan & 0,0175 \\
\hline B1 & Assistance to capital access & 0,0167 \\
\hdashline C4 & Loan term of condition for small business & 0,0164 \\
\hline B11 & IPR assistance & 0,0137 \\
\hdashline B12 & raw material amenity from the government & 0,0110 \\
\hline B6 & Other financial sector policies & 0,0091 \\
\hline A6 & Supporting infrastructure for business place & 0,006 \\
\hline
\end{tabular}

\begin{tabular}{ccc}
\multicolumn{2}{l}{ Internal Factor Priority Improvement } \\
\hline \multicolumn{1}{c}{ Indicator } & $\begin{array}{c}\text { Priority Index } \\
\text { (P index) }\end{array}$ \\
\hline D2 & Innovation on Production Process & 0,0380 \\
E3 & Access to the Internet & 0,0338 \\
\hline F3 & Supply Shortage & 0,0304 \\
E2 & Use of e-Commerce facilities & 0,0198 \\
\hline D1 & Row Material diversifications & 0,0160 \\
\hline${ }^{*}$ Priority & Index $($ sorted $)=$ Importance Weight $(W) x$ Normalize Assesment Score $(a)$
\end{tabular}

Referring to results of the analysis, there are three external factors priority for SMEs improvements, which consist of: First, build a market information system for SMEs, this system will increase opportunities for SMEs to bring their products closer to the market and improve SMEs to collect feedback from their customers. If market has access to SMEs, the customer knowledge sharing process will be created and accelerate the innovation process based on consumer needs. Second, improving the interest rate policy for small businesses. This priority of improvement will accelerate growth and become a foundation for consumer-based innovation which is aligned with first priority decision. Third, the government is expected to be more aggressive and more proactive in providing promotional and endorse facilities to all existing SMEs. These three priorities are a platform for SMEs to be closer to consumers, introduce their products, strengthen working capital and accelerate the innovation process.

On the internal side, the improvement and development priorities consist: first, improve and innovate the production process, by strengthening this, SMEs will get the ability to respond to the market quickly and effectively. Second, increasing access to the internet. This internal capability will have a positive impact if SMEs use the internet for business development activities. Third, internal improvement priorities that must be done by SMEs is to manage the supply of raw materials for production. If raw material procurement and inventory managed properly, then the production process will run effectively and efficiently which will drive the innovation process better.

\section{CONCLuSiON}

Economic growth in most developing countries was supported by their SMEs development. In Indonesia, with a large number of SMEs, the improvement of SME performance will certainly contribute to national macroeconomic growth. Processed food industry based on local resources is a sector that must considerably develop because it is sustainable and has a significant multiplier effect on local economic growth.

Successful SMEs development is not only determined by internal factors but also need to be supported by external factors improvements, joint efforts between the government and entrepreneurs are needed in order to create a business climate that encourages innovation to increase their competitiveness.

Production technology advancement, openness to information and increasing use of the internet as a marketing tool has been encouraging SMEs to transform into innovative business units. For entrepreneurs, this must be seen as an opportunity to carry out various innovations based on customer needs rather than threats. for the government, it is expected to establish progressive policies to accelerate the development of SMEs in a structured manner in accordance with their objective conditions

\section{REFERENCES}

Amabile, T. M., Contti, R., Coon, H., Lazenby, J., \& Herron, M. (1996). Assessing the Work Environment for Creativity Academy of Management Journal, 39(5), 1154-1184.

Anderson, N., Potočnik, K., \& Zhou, J. (2014). Innovation and Creativity in Organizations: A State-of-the-Science Review, Prospective Commentary, and Guiding 
Framework. Journal of Management, 40(5), 12971333. doi: $10.1177 / 0149206314527128$

Argawal, R., Grassl, W., \& Pahl, J. (2012). Meta-SWOT: introducing a new strategic planning tool. Journal of Business Strategy, 33(2), 1-13.

Baregheh, A., Sambrook, S., \& Rowley, J. (2009). Towards a multidisciplinary definition of innovation. Management Decision, 47(8), 1323-1339. doi: 10.1108/00251740910984578

Barnet, H. G. (1953). Innovation: The Basis of Cultural Change. New York: McGraw-Hill.

Barney, J. B. (1991). Firm resources and sustained competitive advantage. Journal of Management, 17(1), 99-120.

Chang, H.-H., \& Huang, W.-C. (2006). Application of a quantification SWOT analytical method. Mathematical and Computer Modelling, 43(1-2), 158-169. doi: 10.1016/j.mcm.2005.08.016

Geenhuizen, M. v., \& Indarti, N. (2005). Knowledge as a Critical Resource in Innovation among Small Furniture Companies in Indonesia. Gadjah Mada International Journal of Business, 7(3), 371-390.

Ghazalian, P. L., \& Fakih, A. (2017). R\&D and Innovation in Food Processing Firms in Transition Countries. Journal of Agricultural Economics, 68(2), 427-450. doi: 10.1111/1477-9552.12186

Godin, B. (2008). Innovation: The History of a Category Project on the Intellectual History of Innovation.

GÜRel, E. (2017). Swot Analysis: A Theoretical Review. Journal of International Social Research, 10(51), 994-1006. doi: 10.17719/jisr.2017.1832

Kanter, R. (1985). Supporting innovation and venture development in established companies. Journal of Business Venturing, 1, 47-60.

Katz, B. R., du Preez, N. D., \& Louw, L. (2016). ALIGNMENT OF INTERNAL AND EXTERNAL BUSINESS AND INNOVATION DOMAINS. South African Journal of Industrial Engineering, 27(1), 6174. doi: 10.7166/27-1-1247

Lidija, B., \& Robert, D. H. (2014). Dynamic capabilities vs. innovation capability: are they related? Journal of Small Business and Enterprise Development, 21(3), 368-384. doi: doi:10.1108/JSBED-02-2014-0018

Myers, A., Oke, A., \& Burke, G. (2007). Innovation types and performance in growing UK SMEs. International Journal of Operations \& Production Management, 27(7), 735-753. doi: 10.1108/01443570710756974

Nassimbeni, G. (2001). Technology, innovation capacity, and the export attitude of small manufacturing firms: a logit/tobit model. Research Policy, 30(2), 245-262.

OECD. (2005). Oslo Manual: Guidelines for Collecting and Interpreting Innovation Data, 3rd Edition: European Commision.
Ozkaya, H. E. (2011). The Antecedent and The Consequences of Innovation Capability. (Doctor of Phylosophy), Michigan State University. (1)

Soto-Acosta, P., Popa, S., \& Palacios-Marqués, D. (2016). Ebusiness, organizational innovation and firm performance in manufacturing SMEs: an empirical study in Spain. Technological \& Economic Development of Economy, 22(6), 885-904. doi: $10.3846 / 20294913.2015 .1074126$

ter Haar, P. (2018). Measuring innovation: A state of the science review of existing approaches. Intangible Capital, 14(3), 409-428. doi: 10.3926/ic.1254

Thompson, V. A. (1965). Bureaucracy and Innovation. Administrative Science Quarterly, 10(1), 1-20. doi: $10.2307 / 2391646$

Ul Hassan, M., Shaukat, S., Nawaz, M. S., \& Naz, S. (2013). Effects of Innovation Types on Firm Performance: an Empirical Study on Pakistan's Manufacturing Sector. Pakistan Journal of Commerce \& Social Sciences, 7(2), 243-262.

Varis, M., \& Littunen, H. (2010). Types of innovation, sources of information and performance in entrepreneurial SMEs. European Journal of Innovation Management, 13(2), 128-154. doi: 10.1108/14601061011040221

Vega-Jurado, J., Gutiérrez-Gracia, A., Fernández-de-Lucio, I., \& Manjarrés-Henríquez, L. (2008). The effect of external and internal factors on firms' product innovation. Research Policy, 37(4), 616-632. doi: https://doi.org/10.1016/j.respol.2008.01.001

Walker, R. M. (2014). Internal and External Antecedents of Process Innovation: A review and extension. Public Management Review, 16(1), 21-44. doi: 10.1080/14719037.2013.771698

West, M. A., \& Farr, J., L. (1990). Innovation at work: John Wiley \& Sons, Ltd. 